\title{
Student's Participation in Class: Between Proximity, Teaching Method, and Communication Intensity
}

\author{
Kristina Yosefina Simorangkir ${ }^{1}$, Rustono Farady Marta ${ }^{2}$, Teguh Priyo Sadono ${ }^{3}$ \\ \{rmarta@bundamulia.ac.id $\left.{ }^{2}\right\}$ \\ Sekolah Bunda Mulia, Jln. A.M. Sangaji No.20, Central Jakarta 10130 - Indonesia ${ }^{1}$, \\ Universitas Bunda Mulia, Jln. Lodan Raya No.2, North Jakarta 14430 - Indonesia23
}

\begin{abstract}
Interpersonal communication defines as the communication applied directly from sender to receiver. In this case, communication that conducted by the teachers to their students has the purpose to build the students motivation to learn and participate actively in the class activities. The purpose of the research is to analyze the effect of proximity variabel between the teachers and students, teaching method through communication intensity applied between teachers and students toward the active participation of students in classroom. The data gathered through cluster random sampling technical with 222 samples from primary school students grade 4 and 5 in Sekolah Bunda Mulia Bilingual Class programme in Central of Jakarta. The analytical method applied by using path analysis from SPSS 20. The result showed that proximity between teachers and students, teachers' teaching method through the intensity of communication do give effect to the participation of students in the class.
\end{abstract}

Keywords: Communication Intensity, Proximity, Student‘s Participation, Teaching Method

\section{Introduction}

Communication is a process of exchanging ideas or opinions carried out by the sources or communicants that accepted by the recipient. Communication is carried out with the aim of changing one's mindset or behavior as quoted from(Cangara, 2014). Communication itself can be interpreted as a social process where each individual has certain symbols that have their own meaning, this is as explained by (West \& Turner, 2014).

There is a different use of communication between traditional learning and modern learning methods. Traditional learning method during teaching and learning process is usually used in the past when the teacher had an active role in giving and presenting learning materials while the students listened to the teacher. Communication types that are linear or one-way are more likely to be used at that time.Along with the development of the times, the forms and techniques of teaching used in the world of education also changing. Modern learning methods are now more likely to be used in various schools, especially in Indonesia.The modern learning method is when the teacher acts as a facilitator in the class and the students have a more active role in class by asking questions or giving their opinions in class.

BundaMulia School located in Central Jakarta is one of the schools where teachers are expected to be able to provide learning with modern teaching methods, where there is a linear communication in the teaching process. The intention of BundaMulia School to create active students can be seen from several subjects that require students to play an active role in class, such as English Conversation, Speaking and Mandarin Conversation. The standard score given for each subject is 70. But, as the result from the data taken in December 2018, most of the students from aged group of 8 to 10 years old in grade 3 and 4 haven't reach the standard score. There were $22.8 \%, 20.2 \%$ and $22.8 \%$ from 153 grade 3 students achieved the standard score (70) and there were 16.9\%, 9.8\% and 18.3\% from 153 grade 3 students achieved below the standard score for the subject English Conversation, Mandarin Conversation and Speaking. While from 155 students of grade 4 there were $26.4 \%, 18.7 \%$ and $24.5 \%$ achieved the standard score (70) and $16.1 \%, 16.7 \%$ and $17.4 \%$ achieved below the standard score for subject English Conversation, Mandarin Conversation and Speaking. From these achievement, it can be seen that the intention of BundaMulia School to create active students is not fully achieved.

The researcher chose 3 and 4 elementary school students as the population in the study as stated by (Scott \& Ytreberg, 1990) in their book that children between the ages of 8 and 10 who generally go to elementary school grades 3 and 4 have a more active character in sharing their opinion or the desire to ask questions to adults. This statement also supported by (Hari, 2012) that students at that age can distinguish 
between fiction and non-fiction, they can adjust to group work and are at a creative and critical age where they have become creators of works and submit their opinions.

This study will identify several research questions that will later help the process of this research: (1) How is the influence between the teacher's and students' proximity on student participation in the class actively?; (2) How is the influence between the teacher's teaching methods in the classroom on the active participation of students in the class?; (3) Is there any influence between the teacher's teaching method and the teacher's proximity to students towards active student participation in the class?

Communication carried out aims to provide motivation to students who tend to be passive to be involved in learning activities and can socialize well with the surrounding environment.In this case, the researcher involved the teacher as the source of the message in motivating the child to participate actively in class. The appropriate communication in applying this research is interpersonal communication. Interpersonal communication as defined by West \& Turner (2014), is a communication carried out directly between the source and the recipient.

Based on UU No. 20 year of 2003 concerning the National Education System from article 1 point 6 explained that educators are educational staffs who work as teachers, lecturers, tutors, counselors, tutors, instructors, facilitators and so on.In this case we can see that the teacher is someone who serves as an educator. As an educator, establishing good relationships with students will have a good impact on student learning. To increase the proximate of a relationship as found in the relationship development models which was a presented by Mark Knapp in the 1980s. By applying this model, it is expected to narrow the gap of a relationship between teacher and student so that it can create close relationships.

The teaching method is a technique used by the teacher in presenting or presenting teaching materials to students in class so that the lessons delivered can be accepted and understood by students. This is as described by (Sudjana, 2005) that the method is a plan that is made thoroughly which serves as a presenter of teaching material using regular and structured language so that it can be well received by students. In this case, researchers will use communicative language teaching learning (CLT) methods. Communicative language teaching is a form of teaching method used by teachers in creating an interactive classroom atmosphere. In communicative language teaching as stated by (Larsen-Freeman \& Anderson, 2011) in their writing that in this teaching method, teachers provide a very important role in forming a communicative learning atmosphere.

Intensity of communication is the level of depth of communication activities between teacher and student or how deeply the teacher and students communicate with one another. This can be connected to the theory of social penetration introduced by Irving Altman and Dalmas Taylor where a relationship is analogous to an onion where there is an outer layer to the core layer. By using communication carried out intensely between teacher and student, it is expected to be able to penetrate the layers in a relationship.

In this study, the author will try to see how the intensity of communication carried out by the teacher and the method of teaching can influence children's participation in the classroom. Research will be conducted using relationship development models and social penetration theory.

Table 1. Research Gap from 4 different previous studies

\begin{tabular}{|c|c|c|c|}
\hline No. & Title of Scientific Journal Article & Writer \& Year & Research Gap \\
\hline 01 & $\begin{array}{l}\text { Teacher-student interpersonal relationships } \\
\text { do change and affect academic motivation: } \\
\text { A multilevel growth curve modeling }\end{array}$ & $\begin{array}{l}\text { Maulana, Opdenakker, } \\
\text { \& Bosker, } 2013\end{array}$ & $\begin{array}{l}\text { The proximity between } \\
\text { teacher and student and } \\
\text { the method of teaching }\end{array}$ \\
\hline 02 & $\begin{array}{l}\text { The role and practice of interpersonal } \\
\text { relationships in European early education } \\
\text { settings: sites for enhancing social inclusion, } \\
\text { personal growth and learning? }\end{array}$ & Kutnick\&Brighi, 2007 & $\begin{array}{l}\text { through the intensity of } \\
\text { communication made } \\
\text { can have an influence } \\
\text { on participation in the }\end{array}$ \\
\hline 03 & $\begin{array}{l}\text { Building Interpersonal Relationship as a Key } \\
\text { to Effective Speaking Center Consultations }\end{array}$ & $\begin{array}{l}\text { Ward \& Schwartzman, } \\
2009\end{array}$ & $\begin{array}{l}\text { class. Especially for } \\
\text { students and students }\end{array}$ \\
\hline \multirow{4}{*}{04} & The Relationship between Teacher-Student & & aged 8 to 10 years in the \\
\hline & Interpersonal Communication and Self- & Rianatha \& Sawitri, & BundaMulia School of \\
\hline & Regulated Learning of Students in SMAN 9 & 2015 & Bilingual Class \\
\hline & Semarang & & Programme \\
\hline
\end{tabular}

In the first previous study is a form of research that shows changes in students' academic motivation in junior high school by creating interpersonal relationships. In the second study, researchers tried to see how positive results were shown in the social life of children in European countries by using 
interpersonal interactions. In the third study, researchers looked at how interpersonal communication can create good relationships between a consultant and obtain information about the client. While the last research that became the previous research in this thesis is a study that shows that interpersonal communication can be used by students to provide an assessment of the teacher and can create good relationships and pleasant classroom atmosphere.

\section{Research Methodology}

This research was designed by using research steps starting from determining the data source, designing the method used to collect data from the source, through this method the researcher will test the hypothesis. In its implementation, a study requires a method to achieve a goal.

This study was designed using the design of the dependent variable, independent and moderator which can be seen as follows:

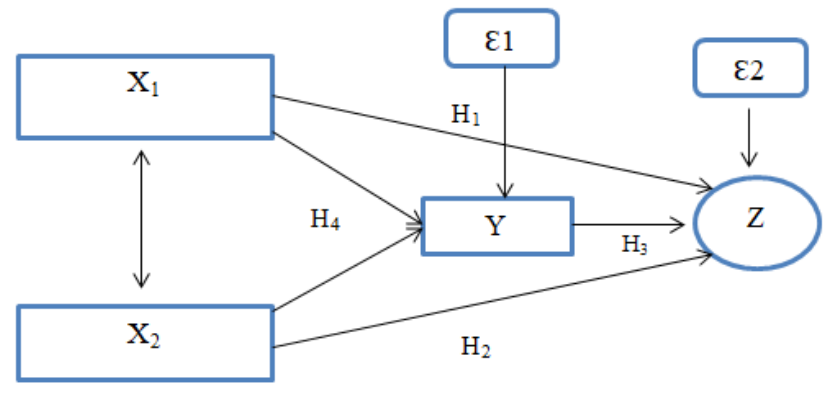

Fig. 1. Research Design as Analysis Structure Between 4 Variables

Based on the design of these variables, it can be seen that several variables examined in this study, namely 1 (one) $\mathrm{Y}$ variable which is an influenced variable, 2 (two) $\mathrm{X}$ variables which are independent variables or influential variables, 1 (one) variable $X$ which is a moderator variable or variable that gives influence and there is $\mathcal{E}$ (epilson) which is another factor that can influence $\mathrm{Y}$ but no further research is conducted.The variables contained in this study are as follows:

$\begin{array}{ll}\mathrm{X}_{1} & : \text { The proximity of teachers and students } \\ \mathrm{X}_{2} & \text { : Method of teaching teachers } \\ \mathrm{Y} & : \text { Communication intensity between teacher and student } \\ \mathrm{Z} & : \text { Active student participation }\end{array}$

In this study, the author will use a quantitative approach. According to (Priyono, 2016), in quantitative, a social symptom is considered as a symptom that is real and can be seen using the human senses. The quantitative approach is a scientific method using thinking that uses the nomothetic principle and uses a deductive pattern. The meaning of the quantitative approach is also presented by (Sugiyono, 2014) that "Research methods that are based on positivism philosophy used to examine certain populations or samples, techniques, random sampling, data collection in research instrument, data analysis quantitative or statistical nature in order to test the predetermined hypothesis".

Students of the Bunda Mulia School who stepped on elementary school grade 3 to 4 from 2018-2019 academic year, with the total of 308 students were the population that would be the object of research. 222 students from 308 were selected as the sample of the study. The sample selected by using the formula of Sovlin as stated from (Umar, 2005).

\section{Findings and Discussion}

The interview research conducted using an interview guide was conducted in February 2019 as described in the previous session. The research was carried out during school hours, the 
researcher explained the intent and purpose of data collection and emphasized to students that no value was taken from the interview to be conducted.The study was conducted when students were working on their worksheets given by their homeroom teacher in class so that the interview did not interfere with the student's learning schedule at school. Interviews are conducted with the help of an interview guide where the interviewer will give 20 questions to students.

In the following of this the researcher will give a comprehensive description of the description of respondents consisting of age and class of respondents. Based on the answers received through interviews using interview guides, it was known that the descriptive identities of the respondents described in Table 2.

Table 2. Descriptive Analysis of Respondents' Data

\begin{tabular}{cccc}
\hline No & Description & $\begin{array}{c}\text { Frequency } \\
\text { (Total of students) }\end{array}$ & $\begin{array}{c}\text { Percentage } \\
(\%)\end{array}$ \\
\hline \multirow{4}{*}{1} & Age & & \\
& 8 years & 80 & $36,03 \%$ \\
& 9 years & 117 & $52,70 \%$ \\
& 10 years & 25 & $11,26 \%$ \\
& Class & & \\
& $3^{\text {rd }}$ Grade of Elementary School & 95 & $42,79 \%$ \\
& $4^{\text {th }}$ Grade of Elementary School & 127 & $57,20 \%$ \\
\hline
\end{tabular}

Based on the data obtained through interviews with 222 respondents from grade 3 and grade 4 students of Bunda Mulia School in Bilingual Class Programme, there were 95 students in grade 3 elementary school or as many as $42.79 \%$ of respondents were grade 3 elementary students and 127 people or $57.20 \%$ of the other respondents were 4 th grade elementary school students. From these data can also be seen based on the age of the respondents, namely as many as 80 students and students with the age of 8 years or equal to $36.03 \%$ of students from 222 respondents aged 8 years. There were 117 respondents aged 9 years or as many as $52.70 \%$ and the rest were students and students aged 10 years, namely 25 people or as many as $11.26 \%$.

Table.3. The Output of Regression Model I

\begin{tabular}{|c|c|c|c|c|c|c|}
\hline \multirow[b]{2}{*}{ Model } & & \multicolumn{2}{|c|}{$\begin{array}{l}\text { Unstandardized } \\
\text { Coefficients }\end{array}$} & \multirow{2}{*}{$\begin{array}{l}\text { Standardized } \\
\text { Coefficients } \\
\text { Beta }\end{array}$} & \multirow[b]{2}{*}{$\mathrm{t}$} & \multirow[b]{2}{*}{ Sig. } \\
\hline & & $\mathrm{B}$ & Std. Error & & & \\
\hline \multirow[t]{3}{*}{1} & (Constant) & 3,352 & 2,869 & & 1,169 & ,244 \\
\hline & $\begin{array}{l}\text { Proximity of } \\
\text { Teacher and Student }\end{array}$ &,- 240 & ,085 &,- 174 & $-2,807$ & ,005 \\
\hline & $\begin{array}{l}\text { Teacher Teaching } \\
\text { Method }\end{array}$ & 1,218 & , 166 & ,454 & 7,332 & , 000 \\
\hline
\end{tabular}

a. Dependent Variable: Students Participation in Class

The model regression output $\mathrm{I}$ in the table section 'coefficients' can be seen that the significance values of the two variables, $\mathrm{X}_{1}$ (Proximityof Teacher and Students) are 0.005 and $\mathrm{X}_{2}$ (Teacher Teaching Method) is 0,000 . Both variables $X_{1}$ and $X_{2}$ have values smaller than 0.05 . This shows that $\mathrm{X}_{1}$ and $\mathrm{X}_{2}$ have a significant influence on $\mathrm{Y}$ (Intensity of Communication between Teacher and Students).

Based on the data analyzed, the path diagram of Structure I is generated as follows:

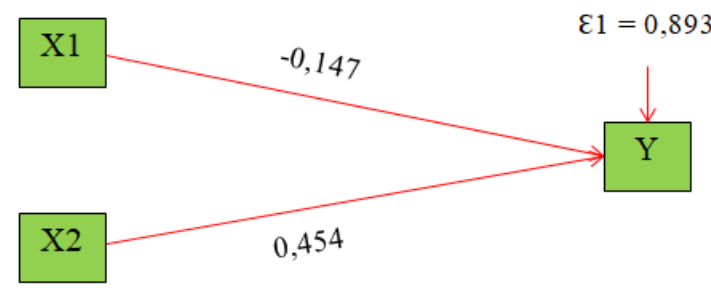

Fig.2. Diagram of Path Structure Model I 
Through the path diagram, the structure model 1 is shown in Figure 1. It can be seen that there is a negative influence between $\mathrm{X}_{1}$ (Proximity between Teacher and Students) and $\mathrm{Y}$ (Intensity of Communication between Teacher and Students). On the other hand there is a significant influence between $\mathrm{X}_{2}$ (Teacher Teaching Method) and Y (Intensity of Communication between Teacher and Students). This indicates that the liner communication between teacher and students in the form of a teaching method CLT (Communicative Language Teaching) is applied in the school as expressed by (Larsen-Freeman \& Anderson, 2011) in their book that two-way communication by teachers to students can create a more active atmosphere in in class.

Table.4. The Output of Regression Model II

\begin{tabular}{|c|c|c|c|c|c|c|}
\hline \multirow{2}{*}{\multicolumn{2}{|c|}{ Model }} & \multicolumn{3}{|r|}{$\begin{array}{l}\text { Standardize } \\
\mathrm{d} \\
\text { Coefficients }\end{array}$} & \multirow[b]{2}{*}{$\mathrm{t}$} & \multirow[b]{2}{*}{ Sig. } \\
\hline & & $\mathrm{B}$ & Std. Error & Beta & & \\
\hline \multirow[t]{4}{*}{1} & (Constant) & 3,608 & 2,800 & & 1,289 & ,199 \\
\hline & Proximity of Teacher and Student &,- 393 &, 094 &,- 284 & $-4,163$ & 000 \\
\hline & Teacher Teaching Method & 1,001 & 174 & ,373 & 5,764 & 000 \\
\hline & $\begin{array}{l}\text { Intensity of Communication between } \\
\text { Teacher and Student }\end{array}$ & ,383 &, 110 &, 254 & 3,467 & ,001 \\
\hline
\end{tabular}

a. Dependent Variable: Participation of Students in Class

The output of regression model II in the 'coefficients' table shows the significance values of the three variables: Variable $\mathrm{X}_{1}$ (Proximity of Teacher and Student) is $0,000, \mathrm{X}_{2}$ (Teacher Teaching Method) is 0,000 and Y Intensity of Communication between Teacher and Student) is 0,001. The three variables $X_{1}, X_{2}$ and $Y$ have values smaller than 0.05. The results of this Regression Model II concluded that $\mathrm{X}_{1}, \mathrm{X}_{2}$ and $\mathrm{Y}$ have an influence on $\mathrm{Z}$ (Student Participation in Class).

Through the data analyzed, the path diagram of structure II is generated as follows:

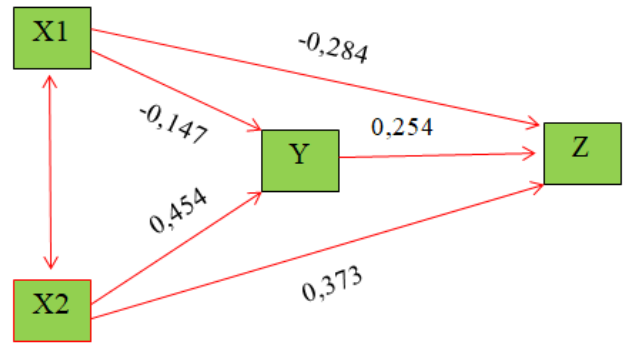

Fig 3. Diagram of Path Structure Model II

The diagram of path structure model II shows that there is an influence between $\mathrm{X}_{1}$ (Proximity of Teacher and Student), $\mathrm{X}_{2}$ (Teacher Teaching Method) and Y (Intensity of Communication between Teacher and Student) to Z (Student Participation in Class).

Based on the results obtained from the research that has been carried out, in this session we will discuss the hypotheses described earlier, which is through analysis that has been obtained from the results of the significance of the variable $\mathrm{X} 1$ to $\mathrm{Z}$ is equal to 0.005 which has a value smaller than $(<0.05)$ 0.05 , it can be concluded that there is an influence between $\mathrm{X}_{1}$ to $\mathrm{Z}$. Based on the data obtained through data analysis using path analysis, there is a significance influence between variable $\mathrm{X}_{2}$ to $\mathrm{Z}$ which is equal to 0,000 . These results have a value that is smaller than $(<0.05) 0.05$. It can be concluded that there is an influence between $X_{2}$ towards Z. From the results obtained through statistical path analysis data, there is a significance result from variable $\mathrm{Y}$ to $\mathrm{Z}$, which is equal to 0.001 . These results have a value smaller than $(<0.05)$ 0.05. In this case it can be concluded that there is an influence between $\mathrm{Y}$ and $\mathrm{Z}$.

According to the results obtained through analysis data, there is a significance of 0,000 from variables $\mathrm{X}_{1}, 0,000$ on variables $\mathrm{X}_{2}$ and 0,001 on variable $\mathrm{Y}$. The three variables have values that are smaller than $(<0,05) 0.05$. Based on these data, it can be concluded that there is an influence between $\mathrm{X}_{1}$ and $\mathrm{X}_{2}$ through $\mathrm{Y}$ to $\mathrm{Z}$.

As discussed earlier, this research was carried out based on present learning methods which were more likely to emphasize students to be able to play an active role and teachers as facilitators in the 
classroom. In other words, students have a more active role in the learning process than teachers who usually become active roles in providing explanations of each teaching material given and students just sit quietly and listen.

This method is also applied in several schools, especially Bunda Mulia School in Bilingual Class Programme in Jakarta which the population is used as the source of this data research. Seeing some of the criteria set as academic determinants of each student at Bunda Mulia School which emphasizes students to be able to play an active role such as a number of lessons that require students to be able to dialogue or speak in class more actively in Speaking lesson, English Conversation and Mandarin Conversation. However, based on the acquisition of values from the 1-2 term as stated in earlier session, it can be seen that the purpose of BundaMulia School to reach students who actively play a role when the learning process is still not achieved.

This is showing contrast to the statement presented by (Scott \& Ytreberg, 1990) and (Hari, 2012) in their writing that children aged 8 to 10 years (generally students in grades 3 and 4) have the ability to think about what they feel or what they want to know. Children at this age also have the courage to give criticism and advice to adults including teachers. Therefore, researchers conducted data collection on students in grade 3 and 4 of elementary school to see several factors that were considered to have an influence on the participation of students and students in playing an active role in class.

\section{Conclusion}

Based on the results of the test through interviews with guide interviews conducted to 222 students as a sample of 308 students it concluded that is a positive influence between the teacher's and students' effectiveness in influencing students to be able to participate in the class. This can be seen based on the results of the significance data indicated by the results of data analysis using path analysis, as well as negative results $(-0,284)$ in standardized beta coefficients which indicate a lack of proximity between teachers and students has a negative influence on student participation in the class. This is also supported by the statement (Pinter, 2006) in her book, that in the learning process, the environment and people around the world provide significant academic influence on young students. This includes the guidance and relationship between teacher and student, the interaction and proximate relationship between teacher and student has a large influence in the learning process of students and students.

There is a positive influence found in the teacher teaching method on student participation in the classroom as is the significance indicated by the results of the analysis of research data. This is also supported by the statement of (Larsen-Freeman \& Anderson, 2011), they said that the method of teaching communicative language teaching where teachers create communicative classes by giving questions as triggers for students to be able to participate in class.

There is a positive influence that can be seen between the intensity of communication between teachers and students towards student participation in the class. This statement is based on significant results from the data obtained previously described. This is also expressed by (Taylor, 1997) as stated in (Jalaluddin, 2009) that when communication is carried out intensely, the more open a person is to reveal himself.

There is an influence between the teacher's and students' proximity and teacher's teaching method through the intensity of the communication between the teacher and the student towards student participation in the class. The results of the data obtained from this study show the significance between variables $\mathrm{X}_{1}, \mathrm{X}_{2}$ through $\mathrm{Y}$ to $\mathrm{Z}$.

In this case, it can be seen that the less active attitudes of students in the Bunda Mulia School based on secondary data obtained in December 2018 in the form of term 1 and term 2 values listed in table 1 can be caused by a lack of Proximity between teacher and student which has an important role in the teaching and learning process as described by (Pinter, 2006). This is seen based on data from 222 samples taken using the Sovlin formula cited from (Umar, 2005)to improve the accuracy of the data obtained. From this study it can also be seen that when there is a proximity between teacher and student and a two-way teaching method created through intense communication between teacher and student can create active students. This can be seen from the significant results in the statistical data obtained. However, seeing the contribution given by each influence variable in this study is not quite large, it is necessary to add other variables that have not been studied and can provide a greater influence on $\mathrm{Z}$ or student participation in the class. 
In this case, it cannot proved that the proximity of teacher and student can be created well without the presence of other external variables which have a large influence. This is as described by (Devito, 1997) that two-way communication or communication between teachers and students conducted using the CLT (Communicative Language Teaching) method cannot fully applied optimally in forming students who actively participate in the class. This can be caused by feedback that is not evenly received by each child so that he cannot reach the goal. (Devito, 1997)also added that empathy also needs to be instilled by the teacher to be able to enter into situations experienced by students, so that communication can be made closer when the teacher can speak using 'language' students and students. Not only is communication done intensely between teacher and student, but the teacher also needs to understand the student's world.

\section{References}

[1]Cangara, H.: Perencanaan dan Strategi Komunikasi. Rajagrafindo Persada, Jakarta (2014)

[2]West, R., \& Turner, L. H.: Introducing Communication Theory. McGraw-Hill Education, New York (2014)

[3]Scott, W. A., \& Ytreberg, L. H.: Teaching English to Children. Longman, New York (1990)

[4]Hari, S. C.: Perkembangan Anak Sejak Pembuahan Sampai Dengan Kanak-Kanak Akhir.

Prenadamedia group, Jakarta (2012)

[5]Sudjana.: Metode Statistika. Tarsito, Bandung (2005)

[6]Larsen-Freeman, D., \& Anderson, M.: Techniques and Principles in Language Teaching. Oxford University Press, New York (2011)

[7]Maulana, R., Opdenakker, M.-C., \& Bosker, R.: Teacher-student interpersonal relationships do change and affect academic motivation: A multilevel growth curve modelling. British Journal of Educational Psychology. pp. 84, 459-482 (2013)

[8]Kutnick, P., \& Brighi, A.: The role and practice of interpersonal relationships in European early education settings: sites for enhancing social inclusion, personal growth and learning? European Early Childhood Education Research Journal. pp. 379-406 (2007)

[9]Ward, K., \& Schwartzman, R.: Building Interpersonal Relationships as a Key to Effective Speaking Center Consultations. Journal of Instructional Psychology. pp. 363-3 (2009)

[10]Rianatha, L., \& Sawitri, D. R.: Hubungan Antara Komunikasi Interpersonal Guru-siswa dengan Self-regulated Learning Pada Siswa SMAN 9 Semarang. Jurnal Empati. pp. 209-213 (2015)

[11]Priyono.: Metode Penelitian Kuantitatif. ZIFATAMA, Surabaya (2006)

[12]Sugiyono.: Metode Penelitian Pendidikan Pendekatan Kuantitatif, Kualitatif, dan R\&D. Alfabeta, Bandung (2014)

[13]Umar, H.: Riset Pemasaran \& Perilaku Konsumen. Gramedia Pustaka, Jakarta (2005)

[14]Pinter, A.: Teaching Young Learners. Oxford University Press, New York (2006)

[15]Jalaluddin, R.: Psikologi Komunikasi. PT Remaja Rosdakarya, Bandung (2009)

[16]Devito, J.: Komunikasi Antar Manusia. Proffesional Books, Jakarta 
